\title{
ENGINEERING SIGNIFICANCE IOF NATIONAL BUREAU OF STANDARDS SOIL-CORROSION DATA
}

\author{
By Kirk H. Logan
}

\section{ABSTRACT}

Approximately 33,000 specimens of various pipe materials have been buried by the National Bureau of Standards in representative soils throughout the United States for the purpose of determining the effects of soils on pipe lines. Early in the investigation it was learned that the rate of penetration of pits on ferrous metals was not constant and that the maximum pit depth on a large specimen was greater than that on a small specimen of the same material. Because of these effects, the results of the tests of small specimens do not show directly what will happen on a pipe line.

The results of soil-corrosion tests should be expressed in terms of three factors. One of these factors represents the inherent corrosiveness of the soil or the pit depth on a unit area for a unit period of exposure. The second factor represents the effect of time on the rate of penetration. The third factor gives the relation of the area from which the maximum pit is measured to the depth of that pit.

Empirical equations which take account of these factors have been suggested, and the constants have been determined for two such equations with respect to 47 of the National Bureau of Standards test sites. This paper presents some of the equations and shows the effect of applying them to the estimation of the condition of a 30-year-old, 8-in. line 1,000 ft. long having a wall thickness of 0.322 in.

A comparison of the computed pit depths with field experience has been attempted for a few soils. It is shown that although no close correlation between the data and experience should be expected, since experiences in the same soil may differ, the data indicate in a general way the corrosiveness of the soils tested.

\section{CONTENTS}

I. Introduction . .

II. Relation between the area from which the deepest pit is measured and its depth........ 111

III. Effect of the duration of the exposure on the depth of the deepest pit..- 114

IV. Extrapolation of soil-corrosion data $\ldots \ldots$

V. Comparison of test data with field experience

VI. Summary

VII. References

\section{INTRODUCTION}

The National Bureau of Standards investigation of the effects of soils on metals began in 1922 with the burial of approximately 7,000 specimens of the commonly used pipe materials in 46 representative soils. Additional specimens have been added from time to time, until the total in 1938 has reached approximately 33,000, of which about two-thirds have been removed for examination.

The original specimens were for the most part samples of ferrous pipes supplied from stock by their manufacturers. The specimens were 6 in. long and $1 \frac{1}{2}, 3$, or 6 in. in nominal diameter. Grease, rust, and loose mill scale were removed. The cut ends were covered with 
a heavy coating of asphalt. The specimens were buried at depths corresponding to the prevailing depths of pipe lines in the localities where the test sites were located. Care was taken to avoid sites subject to stray electric currents.

The rates of penetration of the specimens 6 in. in length, as given in most of the reports [1] ${ }^{1}$ are based on the averages of two deepest pits, one on each of two $1 \frac{1}{2}$-in. specimens or on the average of a proportionally larger number of pits for larger specimens. This is roughly equivalent to taking the unit of area from which to select the deepest pit as 0.2 ft. $^{2}$ In Research Paper 883 [1] estimated maximum pit depths on ferrous specimens of several sizes and materials are also given. These are based on 12 observations.

With few exceptions the ferrous and nonferrous specimens buried in 1932 and 1937 were 11/2-in. pipes approximately 12 in. long or plates having the equivalent area. The reported pit depths are the averages of the deepest pits on each of two specimens and represent areas of approximately $0.4 \mathrm{ft}^{2}{ }^{2}$ In a recent paper [2] by the author and his associates, the area used for computations is $0.4 \mathrm{ft}^{2}{ }^{2}$ The reason for specifying the methods used for reporting the pit-depth data in the papers referred are shown in section II of this paper.

The National Bureau of Standards data on soil corrosion may be employed in the determination of the effects of certain properties or characteristics of soils on corrosion or in the study of the effects of various elements on the resistance of alloys to soil corrosion. For these purposes the methods heretofore used are reasonably satisfactory for presenting data on wrought ferrous materials. Frequently, however, it is desired to estimate the life of a pipe under specified soil conditions or to compare competitive pipe materials. For these purposes it is necessary to take into account certain factors in underground corrosion which until recently, have not been expressed quantitatively.

In this paper the original data on pit depths have been adjusted in accordance with two empirical equations derived largely from pipeline experience for the purpose of showing more clearly the significance of the soil-corrosion data with respect to the corrosion of pipe lines.

The relation between the experimental data and the corrosion of pipes in the vicinities of the test sites is also discussed.

Soils differ greatly in corrosiveness, and their corrosivity is affected by many soil properties. Table 1 shows the maximum and minimum values of certain data on soils at National Bureau of Standards test sites. The range of values for all soils in this country is considerably greater. Widely different soils frequently are to be found within a few hundred feet of each other, and corrosive soils are to be found in most parts of the United States.

Since soil characteristics differ greatly and corrosive soils are widely distributed, it is obvious that no average value for the corrosiveness of soils and no allowance or factor of safety based on average soil conditions should be used in the design of a pipe line to be installed under specific soil conditions. It is necessary in each case to consider the corrosiveness of the soils which the pipe line will encounter if proper account of soil corrosion is to be taken. Any other procedure

\footnotetext{
${ }^{1}$ Numbers in brackets indicate the literature references at the end of this paper.
} 
must result in waste on parts of the line and inadequate protection for other parts.

TABLE 1.-Maximum and minimum values of certain properties of the soils at the National Bureau of Standards test sites ${ }^{1}$

\begin{tabular}{|c|c|c|c|}
\hline Property & Unit & $\begin{array}{c}\text { Maximum } \\
\text { value }\end{array}$ & $\underset{\text { value }}{\text { Minimum }}$ \\
\hline $\begin{array}{l}\text { Electrical resistivity } \\
\text { Moisture equivalent } \\
\text { Air-pore space } \\
\text { Apparent specific gravity } \\
\text { Vclume shrinkage. } \\
\text { Total acidity } \\
\text { pH } \\
\text { Annual precipitation } \\
\text { Mean air temperature } \\
\text { Composition of water extract: } \\
\mathrm{Na}+\mathrm{K} \text { as Na. } \\
\mathrm{Ca} \\
\mathrm{Mg}_{\mathrm{C}} \\
\mathrm{CO} \\
\mathrm{HCO}_{3} \\
\mathrm{Cl}_{3} \\
\mathrm{SO}_{4}\end{array}$ & $\begin{array}{l}\text { Ohm-centimeters } \\
\text { Percent. } \\
\text { Milligram equivalent per } 100 \text { grams of soil } \\
\text { Inches }{ }^{2} \text { do } \\
\text { Milligram equivalent per } 100 \text { grams of soil } \\
\text { do do }\end{array}$ & $\begin{array}{c}54,400 \\
75.5 \\
40.6 \\
2.08 \\
42.7 \\
297.0 \\
10.2 \\
61.6 \\
71.8 \\
45.1 \\
19.24 \\
9.45 \\
4.6 \\
2.1 \\
43.3 \\
46.5\end{array}$ & $\begin{array}{l}32 \\
2.3 \\
1.1 \\
1.41 \\
0 \\
0 \\
2.6 \\
2 \\
39 \\
\\
30 \\
0 \\
0 \\
0 \\
0 \\
0 \\
0\end{array}$ \\
\hline
\end{tabular}

1 Determinations by I. A. Denison, R. B. Hobbs, and I. C. Frost.

2 Data furnished by U. S. Weather Bureau.

8 Zero values are estimated from the specific resistance of the soil.

\section{RELATION BETWEEN THE AREA FROM WHICH THE DEEPEST PIT IS MEASURED AND ITS DEPTH}

Early in the course of the soil-corrosion investigation it was observed that there was a tendency for the specimens which were 3 in. in diameter to contain deeper pits than specimens of similar materials $1 \frac{1}{2}$ in. in diameter. This is illustrated in table 2, which permits a comparison of the maximum pit depths on areas of 66 and 126 in. ${ }^{2}$ of pipe surfaces for two metals exposed for approximately 12 years to 38 soils. Since the specimens differed in diameter, as well as in area, it is possible that the difference in pit depths is affected by differences in curvature of the specimens. However, according to Shepard, [3] the greater curvature of the smaller specimens should tend to concentrate the corrosion and consequently intensify the pitting on the smaller area.

The apparent effect of area seems to be different for different soils and to be slightly different for the two materials. Data, as well as theoretical considerations, indicate that the pit-depth-area relation is influenced by soil characteristics, although just what the characteristics are has not been determined. Sufficient data are not available to determine whether or not the relation is the same for all ferrous materials, but data on pitting factors suggest that the corrosion of wrought iron is somewhat more uniform and that of pit-cast iron somewhat less uniform than that of steel. The difference, however, if any exists, is not great.

The observed values of maximum pit depths are shown in table 3 as a function of the area inspected. In this table are tabulated depths of the deepest pits on each of a number of $20-\mathrm{ft}$ lengths of pipe and also the averages for the depths of the deepest pits on each foot of the corresponding lengths. The data were obtained from measurements made on a 12-in. oil line in Miller clay. The data for individual lengths of pipe rather than the averages for all the lengths are given in order 
that the reader may realize how much pit depths may vary in a single type of soil. It will be noted that the deepest pit on 48 lengths of pipe, $950 \mathrm{ft}$, was 306 mils, the average for depths of the deepest pit on each length of pipe, 208 mils, and the average of the deepest pits on each foot of pipe, 126 mils.

TABLE 2.-Effect of area inspected on the observed maximum pit depths on National Bureau of Standards specimens

[Pit depth in mils.]

\begin{tabular}{|c|c|c|c|c|c|c|c|c|c|}
\hline \multirow{3}{*}{$\begin{array}{c}\text { Soil } \\
\downarrow\end{array}$} & \multicolumn{4}{|c|}{ Depth of maximum pit } & Soil & \multicolumn{4}{|c|}{ Depth of maximum pit } \\
\hline & \multicolumn{2}{|c|}{ Bessemer steel } & \multicolumn{2}{|c|}{ Wrought iron } & \multirow[b]{2}{*}{ Ares $\rightarrow$} & \multicolumn{2}{|c|}{ Bessemer steel } & \multicolumn{2}{|c|}{ Wrought iron } \\
\hline & 66 in. $^{2}$ & 126 in. $^{2}$ & 66 in $^{2}$ & 126 in. ${ }^{2}$ & & 66 in. ${ }^{2}$ & 126 in..$^{2}$ & $66 \mathrm{in.}^{2}$ & 126 in $^{2}$ \\
\hline & $\begin{array}{r}119 \\
71 \\
85 \\
49\end{array}$ & $\begin{array}{r}101 \\
72 \\
84 \\
55\end{array}$ & $\begin{array}{l}81 \\
90 \\
88 \\
52\end{array}$ & $\begin{array}{l}83 \\
96 \\
93 \\
46\end{array}$ & 30 & $\begin{array}{l}73 \\
61 \\
36 \\
48\end{array}$ & $\begin{array}{l}83 \\
69 \\
45 \\
70\end{array}$ & $\begin{array}{l}52 \\
52 \\
31 \\
47\end{array}$ & $\begin{array}{l}59 \\
56 \\
46 \\
67\end{array}$ \\
\hline $\begin{array}{r}6 \ldots \\
7-- \\
8 \ldots \\
9- \\
10-\end{array}$ & $\begin{array}{l}19 \\
46 \\
77 \\
36 \\
43\end{array}$ & $\begin{array}{r}40 \\
65 \\
119 \\
50 \\
60\end{array}$ & $\begin{array}{r}22 \\
43 \\
103 \\
46 \\
54\end{array}$ & $\begin{array}{l}38 \\
48 \\
84 \\
47 \\
52\end{array}$ & 33 & $\begin{array}{l}92 \\
42 \\
28 \\
54 \\
79\end{array}$ & $\begin{array}{r}103 \\
60 \\
90 \\
47 \\
99\end{array}$ & $\begin{array}{r}108 \\
42 \\
42 \\
49 \\
73\end{array}$ & $\begin{array}{r}111 \\
66 \\
59 \\
50 \\
82\end{array}$ \\
\hline $\begin{array}{l}12 \ldots \\
15 \ldots \\
16 \ldots \\
17 \ldots \\
18 \ldots\end{array}$ & $\begin{array}{l}57 \\
58 \\
61 \\
42 \\
44\end{array}$ & $\begin{array}{l}72 \\
85 \\
69 \\
47 \\
50\end{array}$ & $\begin{array}{l}58 \\
61 \\
67 \\
40 \\
48\end{array}$ & $\begin{array}{l}91 \\
83 \\
60 \\
42 \\
43\end{array}$ & $\begin{array}{l}38 \\
39 \\
40 \\
41\end{array}$ & $\begin{array}{r}37 \\
53 \\
73 \\
87 \\
131\end{array}$ & $\begin{array}{r}52 \\
113 \\
83 \\
80 \\
97\end{array}$ & $\begin{array}{r}44 \\
58 \\
71 \\
127 \\
95\end{array}$ & $\begin{array}{l}29 \\
74 \\
70 \\
89 \\
98\end{array}$ \\
\hline $\begin{array}{l}19 \ldots \\
20 \ldots \\
22_{-} \\
24 \ldots \\
26 \ldots\end{array}$ & $\begin{array}{l}78 \\
78 \\
71 \\
25 \\
48\end{array}$ & $\begin{array}{l}61 \\
56 \\
71 \\
31 \\
39\end{array}$ & $\begin{array}{l}71 \\
52 \\
66 \\
25 \\
47\end{array}$ & $\begin{array}{l}79 \\
51 \\
60 \\
29 \\
45\end{array}$ & $\begin{array}{l}43 \\
44 \\
45 \\
46 \\
47\end{array}$ & $\begin{array}{r}108 \\
63 \\
113 \\
75 \\
30\end{array}$ & $\begin{array}{r}90 \\
99 \\
137 \\
136 \\
29\end{array}$ & $\begin{array}{r}80 \\
58 \\
106 \\
72 \\
59\end{array}$ & $\begin{array}{r}173 \\
73 \\
92 \\
80 \\
38\end{array}$ \\
\hline & soils.. & $\ldots$ & $\ldots$ & 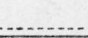 & 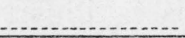 & 63 & 74 & 63 & 68 \\
\hline
\end{tabular}

TABLE 3.-Relation between area inspected and the observed depth of the maximum pit

\begin{tabular}{|c|c|c|c|c|c|}
\hline Pipe section number & $\begin{array}{c}\text { Maximum } \\
\text { pit depth on } \\
\text { each length s }\end{array}$ & $\begin{array}{c}\text { Average pit } \\
\text { depth for 1-ft } \\
\text { lengths }\end{array}$ & Pipe section number & $\begin{array}{l}\text { Maximum } \\
\text { pit depth on } \\
\text { each length a }\end{array}$ & $\begin{array}{l}\text { Average pit } \\
\text { depth for 1-ft } \\
\text { lengths }\end{array}$ \\
\hline $\begin{array}{c}-20 \\
20\end{array}$ & $\begin{array}{rr}\text { Mils } & \\
176 \\
126 \\
183 \\
205 \\
208 \\
202\end{array}$ & \begin{tabular}{r}
\multicolumn{1}{c}{ Mils } \\
90.8 \\
58.6 \\
125.0 \\
126.2 \\
136.7 \\
116.7
\end{tabular} & 25 & 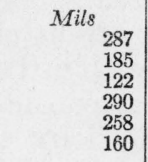 & $\begin{array}{r}\text { Mils } \\
180.0 \\
101.2 \\
65.7 \\
154.7 \\
126.3 \\
94.5\end{array}$ \\
\hline $\begin{array}{l}7 \\
9 \\
11 \\
12\end{array}$ & $\begin{array}{l}227 \\
174 \\
207 \\
217 \\
137 \\
257\end{array}$ & $\begin{array}{r}122.0 \\
138.3 \\
144.3 \\
105.3 \\
79.6 \\
159.3\end{array}$ & 31.10 & $\begin{array}{l}125 \\
258 \\
233 \\
190 \\
188 \\
207\end{array}$ & $\begin{array}{r}67.9 \\
144.4 \\
138.5 \\
115.9 \\
115.8 \\
127.4\end{array}$ \\
\hline $\begin{array}{l}13 \\
14 \\
16 \\
16 \\
18\end{array}$ & $\begin{array}{r}306 \\
202 \\
216 \\
187 \\
179 \\
195\end{array}$ & $\begin{array}{r}169.7 \\
149.9 \\
158.6 \\
139.8 \\
91.3 \\
127.9\end{array}$ & $\begin{array}{l}37 \\
38 \\
39 \\
40 \\
42\end{array}$ & $\begin{array}{l}253 \\
253 \\
154 \\
251 \\
274 \\
185\end{array}$ & $\begin{array}{r}154.6 \\
130.6 \\
94.9 \\
97.6 \\
133.7 \\
121.1\end{array}$ \\
\hline 23 & $\begin{array}{l}200 \\
195 \\
206 \\
245 \\
247 \\
240\end{array}$ & $\begin{array}{l}140.3 \\
143.2 \\
127.7 \\
147.9 \\
152.4 \\
161.1\end{array}$ & $\begin{array}{l}43 \\
44 \\
45 \\
46 \\
48\end{array}$ & $\begin{array}{l}192 \\
164 \\
195 \\
195 \\
237 \\
212\end{array}$ & $\begin{array}{r}138.0 \\
95.5 \\
123.4 \\
141.0 \\
142.8 \\
138.2\end{array}$ \\
\hline Average & & - & (3) & 208 & 126 \\
\hline
\end{tabular}


The relation between the average of the depths of the deepest pits on unit areas and the size of that unit is illustrated in figure 1 . The data for this figure are measurements of the deepest pit on each $20-\mathrm{ft}$. length of 15 miles of a 10-in. pipe line traversing a sandy-loam soil. From these data it was possible to determine the maximum pit depth on areas corresponding to any number of lengths of pipe up to the length of the line.

The lengths of the vertical lines crossing the curve represent four times the standard error of the average of the maximum pit depths. The numbers on the line show the number of observations upon which the average was based. If the pit-depth-area relation were determined for a line traversing more than one soil, the data would obviously be affected by the variety of soils traversed.

Scott [4], after an extensive examination of the Bureau's soil-corrosion data and of the measurements of pits on areas up to $10,000 \mathrm{ft}^{2}$

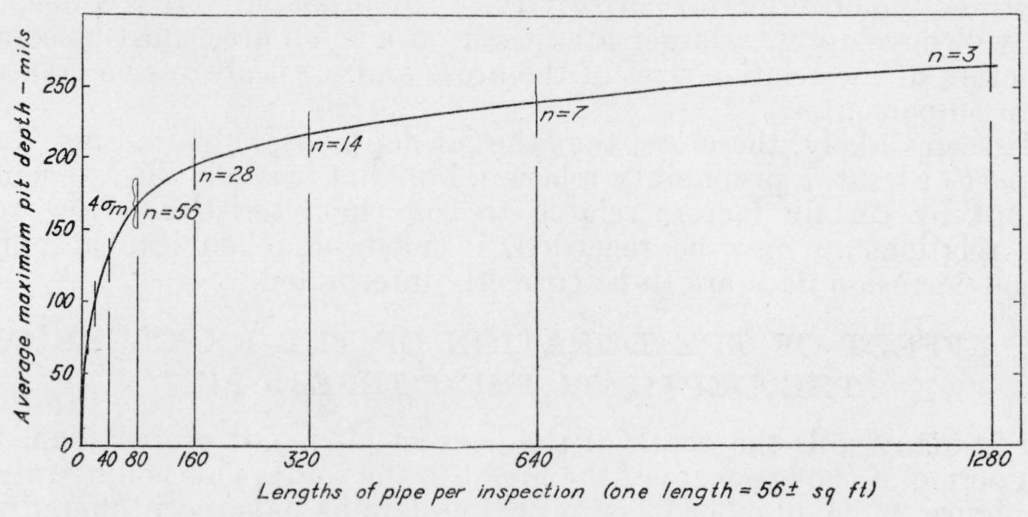

FIgURE 1.-Relation of maximum pit depth to area inspected.

on oil and gas lines, found that the relation between the maximum pit depth and the area from which it was selected could be represented approximately by the equation $P=b A^{\mathrm{a}}$, in which $P$ is the maximum pit depth associated with an area $A$, and $a$ and $b$ are constants which differ for different conditions.

From an unpublished study of data from eight National Bureau of Standards test sites and from seven sets of pipe-line data, Ewing found that on the average, the equation $P=P_{1}(C \log A+1)$, in which $P$ is the maximum pit depth associated with an area $A, P_{1}$ the maximum pit depth on a unit area, and $C$ is a constant varying with conditions, fitted the data better than did Scott's equation.

The fact that buried metal does not corrode uniformly can be accounted for by assuming that conditions over the surface of the metal are not uniform. This condition may be the result of lack of uniformity in the metal, differences in the soil in contact with the metal at different points, or differences in aeration resulting from the way the soil was placed over the surface of the metal. An explanation of the pit-depth-area phenomenon applicable only to small isolated specimens differing in area, is as follows: If a difference of potential exists between two areas on the surface of a specimen, the current which flows between these areas when the circuit is completed through an electrolyte is influenced by the area of the cathode, because of its 
effect on the resistance of the circuit and because of its effect on polarization. The longer the specimen the larger will be the possible area of the cathode. However, there are few data which show definitely what the area of the cathode associated with a single pit is.

If the explanations that have been given fully account for the pit-depth-area relation, it might be expected that when maximum pit depths on a number of specimens having large areas are averaged, some area would be found such that larger areas would not contain deeper pits.

Figure 1 suggests that such may not be the case, since the maximum pit appears to increase in depth with increase in the area chosen for the unit of inspection up to 15 miles of pipe or up to an area of approximately $72,000 \mathrm{ft}^{2}{ }^{2}$

It seems possible that the apparent relation between pit depth and area arises, in part at least, from the use of the maximum pit depth as the criterion for corrosivity. The probability that a deeper pit will develop on a larger area than on a small area must be some function of the relative sizes of the areas and must always be greater than 50 percent.

It seems likely, therefore, that the pit-depth-area relation may be, in part at least, a probability relation, but that it is modified to some extent by certain factors related to soil characteristics. However the relationship may be regarded, it must be taken into account if soil-corrosion data are to be correctly interpreted.

\section{EFFECT OF THE DURATION OF THE EXPOSURE ON THE DEPTH OF THE DEEPEST PIT}

For many soils the depth of the deepest pit is not proportional to the period of the exposure of the metal to the soil. This is illustrated by figure 2. A number of empirical equations have been offered to express the relation of pit depth to the duration of the exposure. Fetherstonhaugh [5] suggested the equation $D=A \sqrt[3]{T}$, in which $D$ is the depth of the pit at any time, $T$, and $A$ is the pit depth for unit time of exposure. Putnam [6] proposed the equation $P=K T^{0.61}$, which differs from Fetherstonhaugh's equation only in the value of the exponent of $T$. These equations indicate that the change in pit depths with time follows a similar course in all soils. That such is not the case is indicated by figure 2 , which shows that after the first few years the increase in the pit depths is roughly proportional to the increase in the period of exposure and that the slopes of the pitdepth-time curves differ greatly for different soils.

Brennan [7], from a study of pipe-line data, decided that the relation of pit depth to time could be represented by the equation $y=(A+B Z) \log (x / h+1)$, where $y$ is the depth of the pit at a time $x, Z$ is the Corfield soil-corrosivity index [8], and $A, B$, and $h$ are constants to be derived from a study of test data.

Scott [9], after analyzing the National Bureau of Standards data, decided that the relation of pit depth to time could be represented approximately by the equation $P=U T /(B+T)$, in which $P$ is the pit depth at time $T$, and $U$ and $B$ are constants which characterize the soil.

Ewing found that the occurrence of leaks on pipe lines was consistent with the equation $P=k T^{n}$, in which $k$ and $n$ are constants depending on soil characteristics. Denison [2] found that this equa- 
tion was also applicable to the Bureau's data. This equation differs from those of Fetherstonhaugh and Putnam in that it does not require that all pit-depth-time curves shall have the same general shape. This equation has been used in several papers prepared by members of the staff of the National Bureau of Standards and by some others, and it is used in this paper.

Values of the constants $k$ and $n$ have been determined for the soils at the National Bureau of Standards test sites, where the accumulated data justify an attempt to fix their values. The value of $k$ has been associated with the fundamental corrosivity of the soil, whereas $n$ seems to be related to the aeration of the soil. The degree of aeration

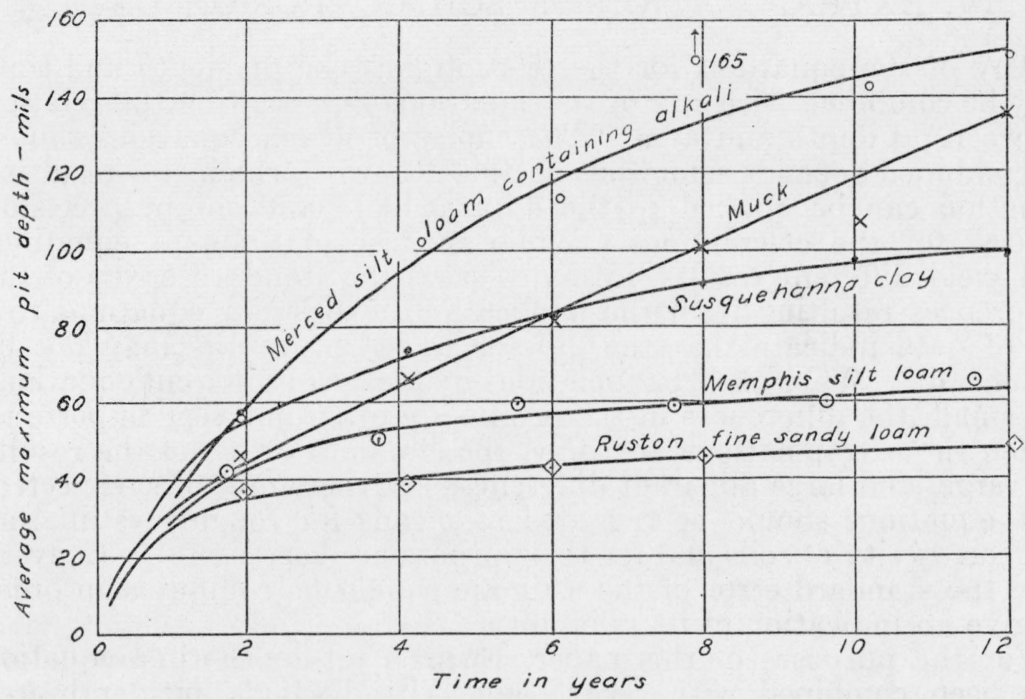

FIgURE 2.-Relation of maximum depth of pits to duration of exposure.

of a soil largely determines the effectiveness of the corrosion products in protecting the metal against continued corrosion. Based on the relation of aeration to corrosion, values of $n$ to be used in the absence of data from which they can be determined directly have been assigned [2] to classes of soils according to their aeration.

A great deal of stress has been placed on the fact that the rate of corrosion decreases with the period of exposure. For most soils the relation between pit depths and the age of the pipe buried therein can be represented approximately by some curved line. However for many soils the bending of the curves is very slight after the first few years of exposure and the equation for a straight line, $P=a+b x$, will approximate the shape of the curve beyond the first few years of exposure almost as well as a more complicated equation, because, at best, the data on pit depths are not precise.

The assumption that maximum pit depths are proportional to the period of exposure of the pipe leads to estimates of pipe life that are much too low when the estimates are based on pit depths on pipes that have been exposed to well-aerated soils for only a few years. However, when the exposures to these soils are long or when the pipes are exposed to very poorly aerated soils, the errors resulting from the above assumption may be no larger than the allowances 
which must be made because of the lack of precision in the original observations. Since a large part of the severely corrosive soils are poorly aerated, too much reliance should not be placed on the possibility of a decline in the rate of corrosion.

All of the equations which have been given are empirical and approximately represent the relations between pit depth and time or area. The dispersions of soil-corrosion data are such that no simple equation could fit all of the data exactly. For any one set of data one of the equations may fit better than the other equations, but none of the equations fits all the data better than all other equations.

\section{EXTRAPOLATION OF SOIL-CORROSION DATA}

Any of the equations for the relation between pit depth and time may be combined with any of the equations representing the relation between pit depth and area. The choice of which equations should be combined depends somewhat on the ease with which the resulting equation can be applied to the data at hand and on the precision desired for the calculations. While the use of different equations will yield different results, in many cases the standard errors of the differences resulting from the application of different equations to a set of data indicate that the differences in the results may not be significant. When the extrapolations by means of different equations are small, the differences in the results are often not very important. When the extrapolations are large, the standard errors of the results are large, and large apparent differences are therefore to be expected. The equations should be regarded as means for roughly estimating the corrosivity of soils and for this purpose are very useful. In every case the standard error of the estimate should be computed in order to give an indication of its reliability.

For the purposes of this paper, Ewing's pit-depth-time equation has been combined with Scott's and with Ewing's pit-depth-area equations. This gives the following equations, respectively, $P=$ $k T^{n} A^{a}$ and $P=k T^{n}(C \log A+1)$, in which $P$ is the pit depth on an area, $A$, at any time, $T$, and $C, a, k$, and $n$ are constants derived from an analysis of the data on pit depths. Table 4 gives the values of these constants for 47 soils. By means of the equations given above, the average depth of the deepest pits on 1,000 linear $\mathrm{ft}$ of 8 -in. pipe exposed 30 years were calculated. By rearrangement of the equations it was possible to calculate the average length of pipe associated with a puncture in 30 years and the time required for an average of one puncture of the pipe wall per $1,000 \mathrm{ft}$ of pipe. These values are also shown in table 4 . Since the data for pure openhearth iron, wrought iron, Bessemer steel, open-hearth steel, and open-hearth steel containing 0.2 percent of copper were not definitely different, they were averaged for the calculation of the constants in table 4. The data for cast iron were more erratic and were not used on this account.

The values of $k_{5.3}$, column 5 , are the averages of maximum pit depth on specimens having areas of $0.4 \mathrm{ft}^{2}{ }^{2}$ Their exposure was 5.3 years. The values of $k_{5.3}$ range between 21 and 107 mils. The values of the area factor, $a$, column 3 , range from 0.08 to 0.32 . The values of the time factor, $n$, column 7 , range between 0 and 0.92 . 
TABLE 4.-Calculated data on pit depths and leaks on a pipe line

[Length of unit section 1,000 feet, diameter of pipe 8.625 inches, thickness of pipe wall 322 mils]

\begin{tabular}{|c|c|c|c|c|c|c|c|c|c|c|c|c|c|c|c|c|c|}
\hline \multicolumn{2}{|r|}{ Soil } & \multicolumn{8}{|c|}{ Constants } & \multicolumn{4}{|c|}{ Scott's pit-depth-area equation } & \multicolumn{4}{|c|}{ Ewing's pit-depth-area equation } \\
\hline No. & Type & $a$ & $\sigma_{a}$ & $k_{5.3}$ & $\sigma_{k_{5.8}}$ & $n$ & $\sigma_{n}$ & C.4 & $\sigma_{C .4}$ & $\begin{array}{l}\text { Deep- } \\
\text { est pit } \\
\text { in } 30 \\
\text { years }\end{array}$ & $\begin{array}{l}\text { Stand- } \\
\text { ard } \\
\text { error }\end{array}$ & $\begin{array}{c}\text { Length } \\
\text { of pipe } \\
\text { per } \\
\text { puncture } \\
\text { in } 30 \\
\text { years }\end{array}$ & $\begin{array}{c}\text { Time for } \\
\text { puncture } \\
\text { per } 1,000 \\
\text { feet of } \\
\text { pipe }\end{array}$ & $\begin{array}{l}\text { Deep- } \\
\text { est pit } \\
\text { in } 30 \\
\text { years }\end{array}$ & $\begin{array}{l}\text { Stand- } \\
\text { ard } \\
\text { error }\end{array}$ & \begin{tabular}{|} 
Length \\
of pipe \\
per \\
puncture \\
in 30 \\
years
\end{tabular} & $\begin{array}{l}\text { Time for } \\
\text { puncture } \\
\text { per } 1,000 \\
\text { feet of } \\
\text { pipe }\end{array}$ \\
\hline 1 & 2 & 3 & 4 & 5 & 6 & 7 & 8 & 9 & 10 & 11 & 12 & 13 & 14 & 15 & 16 & 17 & 18 \\
\hline $\begin{array}{l}1 \\
2 \\
3 \\
4 \\
5\end{array}$ & $\begin{array}{l}\text { Allis silt loam } \\
\text { Bell clay } \\
\text { Cecil clay loam } \\
\text { Chester loam } \\
\text { Dublin clay adobe }\end{array}$ & $\begin{array}{l}0.146 \\
.131 \\
.144 \\
.160 \\
.144\end{array}$ & $\begin{array}{l}0.021 \\
.030 \\
.024 \\
.020 \\
.030\end{array}$ & $\begin{array}{l}58.5 \\
45.4 \\
68.8 \\
51.6 \\
37.0\end{array}$ & $\begin{array}{l}2.7 \\
2.2 \\
2.3 \\
6.4 \\
3.0\end{array}$ & $\begin{array}{l}0.49 \\
.34 \\
.17 \\
.59 \\
.47\end{array}$ & $\begin{array}{l}0.06 \\
.08 \\
.05 \\
.17 \\
.13\end{array}$ & $\begin{array}{r}0.417 \\
.370 \\
.413 \\
.459 \\
.407\end{array}$ & $\begin{array}{r}0.069 \\
.099 \\
.082 \\
.068 \\
.106\end{array}$ & \begin{tabular}{c|} 
Mils \\
475 \\
254 \\
320 \\
572 \\
290
\end{tabular} & \begin{tabular}{r|} 
Mils \\
103 \\
76 \\
73 \\
208 \\
102
\end{tabular} & \begin{tabular}{|} 
Feet \\
$6.2 \times 10$ \\
$6.1 \times 10^{3}$ \\
$1.0 \times 10^{3}$ \\
$6.3 \times 10^{3}$ \\
$2.0 \times 10^{3}$
\end{tabular} & $\begin{array}{r}\text { Years } \\
13 \\
60 \\
31 \\
11 \\
37\end{array}$ & $\begin{array}{r}\text { Mils } \\
351 \\
195 \\
235 \\
390 \\
211\end{array}$ & $\begin{array}{r}\text { Mils } \\
53 \\
42 \\
36 \\
130 \\
61\end{array}$ & $\begin{array}{l}\quad \text { Feet } \\
3.1 \times 10^{2} \\
i .6 \times 10^{7} \\
1.9 \times 10^{5} \\
9.1 \times 10^{5} \\
1.8 \times 10^{6}\end{array}$ & $\begin{array}{r}\text { Years } \\
25 \\
130 \\
190 \\
22 \\
74\end{array}$ \\
\hline $\begin{array}{r}6 \\
7 \\
8 \\
9 \\
10\end{array}$ & $\begin{array}{l}\text { Everett gravelly sandy loam } \\
\text { Fairmount silt loam } \\
\text { Fargo clay loam } \\
\text { Genesee silt loam } \\
\text { Gloucester sandy loam }\end{array}$ & $\begin{array}{l}.144 \\
.116 \\
.133 \\
.172 \\
.184\end{array}$ & $\begin{array}{l}.028 \\
.009 \\
.009 \\
.028 \\
.027\end{array}$ & $\begin{array}{l}21.7 \\
31.1 \\
64.4 \\
44.0 \\
37.2\end{array}$ & $\begin{array}{l}1.1 \\
2.0 \\
0.9 \\
5.4 \\
3.2\end{array}$ & $\begin{array}{l}0 \\
.46 \\
.32 \\
.16 \\
.42\end{array}$ & $\begin{array}{l}.05 \\
.07 \\
.07 \\
.15 \\
.13\end{array}$ & $\begin{array}{l}.409 \\
.309 \\
.365 \\
.511 \\
.553\end{array}$ & \begin{tabular}{l||}
.092 \\
.026 \\
.032 \\
.107 \\
.099
\end{tabular} & $\begin{array}{r}75 \\
188 \\
353 \\
257 \\
378\end{array}$ & \begin{tabular}{r|}
20 \\
30 \\
51 \\
97 \\
127
\end{tabular} & $\begin{array}{l}2.4 \times 107 \\
1.0 \times 10^{5} \\
4.9 \times 10^{2} \\
3.7 \times 10^{3} \\
4.2 \times 10^{2}\end{array}$ & \begin{tabular}{r|}
$\infty$ \\
97 \\
22 \\
120 \\
20
\end{tabular} & $\begin{array}{r}55 \\
149 \\
266 \\
169 \\
237\end{array}$ & $\begin{array}{r}9 \\
22 \\
35 \\
54 \\
64\end{array}$ & $\begin{array}{c}\infty \\
1.3 \times 10^{11} \\
2.4 \times 10^{4} \\
1.4 \times 10^{8} \\
1.0 \times 10^{5}\end{array}$ & $\begin{array}{r}\infty \\
160 \\
55 \\
170 \\
62\end{array}$ \\
\hline $\begin{array}{l}11 \\
12 \\
13 \\
14 \\
15\end{array}$ & $\begin{array}{l}\text { Hagerstown loam } \\
\text { Hanford fine sandy loam } \\
\text { Hanford very fine sandy loam. } \\
\text { Hempstead silt loam } \\
\text { Houston black clay. }\end{array}$ & $\begin{array}{l}.140 \\
.140 \\
.193 \\
.158 \\
.100\end{array}$ & $\begin{array}{l}.021 \\
.031 \\
.015 \\
.033 \\
.015\end{array}$ & $\begin{array}{l}62.9 \\
51.2 \\
63.7 \\
85.5 \\
51.4\end{array}$ & $\begin{array}{r}2.7 \\
14.0 \\
7.8 \\
4.5 \\
3.6\end{array}$ & $\begin{array}{l}.32 \\
.13 \\
.18 \\
.48 \\
.32\end{array}$ & $\begin{array}{l}.06 \\
.73 \\
.20 \\
.07 \\
.11\end{array}$ & $\begin{array}{l}.396 \\
.398 \\
.573 \\
.472 \\
.265\end{array}$ & $\begin{array}{l}.071 \\
.109 \\
.055 \\
.123 \\
.044\end{array}$ & $\begin{array}{l}367 \\
215 \\
465 \\
770 \\
212\end{array}$ & $\begin{array}{r}78 \\
284 \\
181 \\
241 \\
155\end{array}$ & $\begin{array}{l}3.9 \times 10^{2} \\
1.7 \times 10^{4} \\
1.6 \times 10^{2} \\
4.0 \\
6.4 \times 10^{4}\end{array}$ & $\begin{array}{r}20 \\
670 \\
4 \\
5 \\
110\end{array}$ & $\begin{array}{l}272 \\
159 \\
275 \\
545 \\
178\end{array}$ & $\begin{array}{r}42 \\
208 \\
100 \\
116 \\
39\end{array}$ & $\begin{array}{l}1.4 \times 10^{4} \\
2.4 \times 10^{0} \\
8.8 \times 10^{3} \\
4.0 \\
1.2 \times 10^{8}\end{array}$ & $\begin{array}{r}51 \\
6,500 \\
74 \\
10 \\
190\end{array}$ \\
\hline $\begin{array}{l}16 \\
17 \\
18 \\
19 \\
20\end{array}$ & $\begin{array}{l}\text { Kalmia fine sandy loam } \\
\text { Keyport loam } \\
\text { Knox silt loam } \\
\text { Lindley clay loam } \\
\text { Mahoning silt loam }\end{array}$ & $\begin{array}{l}.118 \\
.125 \\
.111 \\
.103 \\
.188\end{array}$ & $\begin{array}{l}.017 \\
.038 \\
.018 \\
.010 \\
.038\end{array}$ & $\begin{array}{l}66.0 \\
33.1 \\
46.0 \\
51.9 \\
34.7\end{array}$ & $\begin{array}{l}3.7 \\
1.9 \\
5.8 \\
1.6 \\
3.0\end{array}$ & $\begin{array}{l}.32 \\
.19 \\
.18 \\
.34 \\
.43\end{array}$ & $\begin{array}{l}.13 \\
.07 \\
.12 \\
.04 \\
.10\end{array}$ & $\begin{array}{l}.320 \\
.360 \\
.301 \\
.270 \\
.584\end{array}$ & $\begin{array}{l}.053 \\
.123 \\
.053 \\
.026 \\
.131\end{array}$ & $\begin{array}{l}319 \\
136 \\
164 \\
226 \\
371\end{array}$ & $\begin{array}{r}88 \\
48 \\
47 \\
28 \\
120\end{array}$ & $\begin{array}{l}1.0 \times 10^{3} \\
1.0 \times 10^{6} \\
4.4 \times 10^{5} \\
2.8 \times 10^{4} \\
4.7 \times 10^{2}\end{array}$ & $\begin{array}{r}31 \\
2,900 \\
1,300 \\
83 \\
22\end{array}$ & $\begin{array}{l}252 \\
108 \\
134 \\
188 \\
234\end{array}$ & $\begin{array}{l}63 \\
26 \\
35 \\
17 \\
58\end{array}$ & $\begin{array}{l}7.8 \times 10^{4} \\
8.7 \times 10^{15} \\
8.2 \times 10^{12} \\
2.0 \times 10^{8} \\
1.2 \times 10^{5}\end{array}$ & $\begin{array}{r}64 \\
9,400 \\
4,000 \\
140 \\
63\end{array}$ \\
\hline $\begin{array}{l}21 \\
22 \\
23 \\
24 \\
25\end{array}$ & $\begin{array}{l}\text { Marshall silt loam } \\
\text { Memphis silt loam } \\
\text { Merced silt loam } \\
\text { Merrimac gravelly sandy loam } \\
\text { Miami clay loam }\end{array}$ & $\begin{array}{l}.129 \\
.082 \\
.139 \\
.172 \\
.088\end{array}$ & $\begin{array}{l}.012 \\
.009 \\
.044 \\
.035 \\
.008\end{array}$ & $\begin{array}{r}55.7 \\
57.7 \\
107.3 \\
22.7 \\
40.8\end{array}$ & $\begin{array}{l}3.1 \\
1.1 \\
2.9 \\
1.6 \\
2.0\end{array}$ & $\begin{array}{l}.60 \\
.21 \\
.51 \\
.11 \\
.29\end{array}$ & $\begin{array}{l}.07 \\
.03 \\
.04 \\
.09 \\
.06\end{array}$ & $\begin{array}{l}.351 \\
.212 \\
.391 \\
.515 \\
.227\end{array}$ & $\begin{array}{l}.033 \\
.024 \\
.140 \\
.128 \\
.026\end{array}$ & $\begin{array}{l}480 \\
169 \\
863 \\
121 \\
144\end{array}$ & $\begin{array}{r}81 \\
16 \\
334 \\
42 \\
19\end{array}$ & $\left|\begin{array}{l}4.5 \times 10 \\
2.7 \times 10^{6} \\
0.8 \\
2.9 \times 10^{5} \\
9.2 \times 10^{6}\end{array}\right|$ & $\left|\begin{array}{r}15 \\
650 \\
4 \\
2.1 \times 10^{8} \\
480\end{array}\right|$ & $\begin{array}{r}364 \\
149 \\
640 \\
80 \\
125\end{array}$ & $\begin{array}{r}52 \\
11 \\
144 \\
19 \\
16\end{array}$ & $\begin{array}{l}1.7 \times 10^{2} \\
6.9 \times 10^{12} \\
0.7 \\
1.1 \times 10^{20} \\
7.7 \times 10^{15}\end{array}$ & $\begin{array}{r}24 \\
1,200 \\
8 \\
8.8 \times 10^{6} \\
780\end{array}$ \\
\hline
\end{tabular}


TABLE 4.-Calculated data on pit depths and leaks on a pipe line-Continued

\begin{tabular}{|c|c|c|c|c|c|c|c|c|c|c|c|c|c|c|c|c|c|}
\hline \multicolumn{2}{|r|}{ Soil } & \multicolumn{8}{|c|}{ Constants } & \multicolumn{4}{|c|}{ Scott's pit-depth-area equation } & \multicolumn{4}{|c|}{ Ewing's pit-depth-area equation } \\
\hline No. & Type & $a$ & $\sigma_{a}$ & $k_{5.3}$ & $\sigma_{k_{5.3}}$ & $n$ & $\sigma_{n}$ & $C .4$ & $\sigma_{C_{.4}}$ & $\begin{array}{l}\text { Deep- } \\
\text { est pit } \\
\text { in } 30 \\
\text { years }\end{array}$ & $\begin{array}{l}\text { Stand- } \\
\text { ard } \\
\text { error }\end{array}$ & $\begin{array}{l}\text { Length } \\
\text { of pipe } \\
\text { per } \\
\text { puncture } \\
\text { in } 30 \\
\text { years }\end{array}$ & $\begin{array}{l}\text { Time for } \\
\text { puncture } \\
\text { per } 1,000 \\
\text { feet of } \\
\text { pipe }\end{array}$ & $\begin{array}{l}\text { Deep- } \\
\text { est pit } \\
\text { in } 30 \\
\text { years }\end{array}$ & $\begin{array}{l}\text { Stand- } \\
\text { ard } \\
\text { error }\end{array}$ & $\begin{array}{c}\text { Length } \\
\text { of pipe } \\
\text { per } \\
\text { puncture } \\
\text { in } 30 \\
\text { years }\end{array}$ & $\begin{array}{l}\text { Time for } \\
\text { puncture } \\
\text { per } 1,000 \\
\text { feet of } \\
\text { pipe }\end{array}$ \\
\hline 1 & 2 & 3 & 4 & 5 & 6 & 7 & 8 & 9 & 10 & 11 & 12 & 13 & 14 & 15 & 16 & 17 & 18 \\
\hline $\begin{array}{l}26 \\
27 \\
28 \\
29 \\
30\end{array}$ & $\begin{array}{l}\text { Miami silt loam } \\
\text { Miller clay } \\
\text { Montezuma clay adobe. } \\
\text { Muck } \\
\text { Muscatine silt loam }\end{array}$ & $\begin{array}{l}.120 \\
.170 \\
.106 \\
.178 \\
.123\end{array}$ & $\begin{array}{l}.028 \\
.037 \\
.005 \\
.043 \\
.033\end{array}$ & $\begin{array}{l}45.7 \\
38.1 \\
86.0 \\
92.0 \\
32.1\end{array}$ & $\begin{array}{r}7.1 \\
1.6 \\
13.2 \\
2.0 \\
7.0\end{array}$ & $\begin{array}{l}.41 \\
.65 \\
.92 \\
.60 \\
.53\end{array}$ & $\begin{array}{l}.22 \\
.08 \\
.22 \\
.03 \\
.26\end{array}$ & $\begin{array}{l}.336 \\
.511 \\
.277 \\
.538 \\
.351\end{array}$ & $\begin{array}{l}.091 \\
.130 \\
.041 \\
.152 \\
.112\end{array}$ & $\begin{array}{r}\text { Mils } \\
262 \\
511 \\
1,059 \\
1,211 \\
233\end{array}$ & $\begin{array}{r}\text { Mils } \\
125 \\
179 \\
437 \\
455 \\
139\end{array}$ & $\begin{array}{l}\quad \text { Feet } \\
5.5 \times 10^{3} \\
3.2 \times 10^{2} \\
0.01 \\
0.6 \\
1.3 \times 10^{4}\end{array}$ & $\begin{array}{r}\text { Years } \\
49 \\
15 \\
8 \\
5 \\
55\end{array}$ & $\begin{array}{r}\text { Mils } \\
211 \\
343 \\
865 \\
783 \\
187\end{array}$ & $\begin{array}{r}\text { Mils } \\
93 \\
76 \\
362 \\
154 \\
100\end{array}$ & $\begin{array}{l}\quad \text { Feet } \\
3.6 \times 10^{6} \\
4.4 \times 10^{2} \\
0.02 \\
.50 \\
6 \times 10^{7}\end{array}$ & $\begin{array}{r}\text { Years } \\
85 \\
27 \\
10 \\
7 \\
84\end{array}$ \\
\hline $\begin{array}{l}31 \\
32 \\
33 \\
34 \\
35\end{array}$ & $\begin{array}{l}\text { Norfolk sand } \\
\text { Ontario loam } \\
\text { Peat_ sit loam } \\
\text { Penn sil loam } \\
\text { Ramona lo }\end{array}$ & $\begin{array}{l}.172 \\
.165 \\
.168 \\
.157 \\
.318\end{array}$ & $\begin{array}{l}.027 \\
.039 \\
.028 \\
.012 \\
.067\end{array}$ & $\begin{array}{l}40.4 \\
44.8 \\
56.4 \\
41.0 \\
26.5\end{array}$ & $\begin{array}{l}2.0 \\
2.6 \\
7.1 \\
5.4 \\
1.3\end{array}$ & $\begin{array}{l}0 \\
.33 \\
.74 \\
.54 \\
.25\end{array}$ & $\begin{array}{l}.08 \\
.07 \\
.16 \\
.18 \\
.08\end{array}$ & $\begin{array}{r}.508 \\
.502 \\
.500 \\
.447 \\
1.227\end{array}$ & $\begin{array}{l}.095 \\
.138 \\
.109 \\
.042 \\
.321\end{array}$ & $\begin{array}{l}179 \\
330 \\
868 \\
406 \\
638\end{array}$ & $\begin{array}{r}49 \\
120 \\
338 \\
144 \\
381\end{array}$ & $\begin{array}{l}3.0 \times 10^{4} \\
8.6 \times 10^{2} \\
2.7 \\
2.3 \times 10^{2} \\
1.2 \times 10^{2}\end{array} \mid$ & \begin{tabular}{r|}
$\infty$ \\
28 \\
8 \\
19 \\
2
\end{tabular} & $\begin{array}{l}117 \\
229 \\
585 \\
280 \\
229\end{array}$ & $\begin{array}{r}22 \\
51 \\
197 \\
96 \\
60\end{array}$ & $\begin{array}{l}9.1 \times 10^{12} \\
2.2 \times 10^{5} \\
2.6 \\
7.9 \times 10^{3} \\
7.3 \times 10^{4}\end{array}$ & $\begin{array}{r}\infty \\
84 \\
13 \\
39 \\
120\end{array}$ \\
\hline $\begin{array}{l}36 \\
37 \\
38 \\
39 \\
40\end{array}$ & $\begin{array}{l}\text { Ruston sandy loam } \\
\text { St. Johns fine sand } \\
\text { Sassafras gravelly sandy loam } \\
\text { Sassafras silt loam } \\
\text { Sharkey clay }\end{array}$ & $\begin{array}{l}.097 \\
.191 \\
.153 \\
.150 \\
.144\end{array}$ & $\begin{array}{l}.014 \\
.017 \\
.028 \\
.015 \\
.019\end{array}$ & $\begin{array}{l}45.4 \\
65.4 \\
27.5 \\
47.4 \\
60.9\end{array}$ & $\begin{array}{l}0.9 \\
3.7 \\
0.4 \\
2.4 \\
3.9\end{array}$ & $\begin{array}{l}.14 \\
.27 \\
.23 \\
.51 \\
.50\end{array}$ & $\begin{array}{l}.03 \\
.09 \\
.02 \\
.07 \\
.10\end{array}$ & $\begin{array}{l}.255 \\
.570 \\
.443 \\
.424 \\
.405\end{array}$ & $\begin{array}{l}.041 \\
.063 \\
.095 \\
.051 \\
.064\end{array}$ & $\begin{array}{l}134 \\
544 \\
154 \\
419 \\
503\end{array}$ & $\begin{array}{r}20 \\
121 \\
38 \\
78 \\
124\end{array}$ & $\left|\begin{array}{l}8.6 \times 10^{3} \\
6.4 \times 10^{\circ} \\
1.2 \times 10^{5} \\
1.7 \times 10^{2} \\
4.5 \times 10^{2}\end{array}\right|$ & $\begin{array}{r}1.5 \times 104 \\
4 \\
750 \\
18 \\
12\end{array}$ & $\begin{array}{l}114 \\
328 \\
109 \\
297 \\
365\end{array}$ & $\begin{array}{l}11 \\
60 \\
15 \\
45 \\
76\end{array}$ & $\begin{array}{l}1.2 \times 10^{17} \\
7.8 \times 10^{2} \\
5.6 \times 10^{14} \\
3.2 \times 10^{3} \\
1.8 \times 10^{2}\end{array} \mid$ & $\begin{array}{r}5.2 \times 10^{4} \\
28 \\
3.3 \times 10^{3} \\
35 \\
23\end{array}$ \\
\hline $\begin{array}{l}41 \\
42 \\
43 \\
44 \\
45\end{array}$ & $\begin{array}{l}\text { Summit silt loam } \\
\text { Susquehanna clay } \\
\text { Tidal marsh } \\
\text { Wabash silt loam } \\
\text { Unidentified alkali soil }\end{array}$ & $\begin{array}{l}.095 \\
.098 \\
.195 \\
.148 \\
.142\end{array}$ & $\begin{array}{l}.018 \\
.009 \\
.023 \\
.038 \\
.025\end{array}$ & $\begin{array}{l}54.8 \\
84.7 \\
83.2 \\
58.5 \\
54.3\end{array}$ & $\begin{array}{l}3.9 \\
0.4 \\
4.0 \\
0.4 \\
6.8\end{array}$ & $\begin{array}{l}.39 \\
.30 \\
.47 \\
.30 \\
.78\end{array}$ & $\begin{array}{l}.20 \\
.006 \\
.06 \\
.009 \\
.16\end{array}$ & $\begin{array}{l}.252 \\
.256 \\
.590 \\
.440 \\
.406\end{array}$ & $\begin{array}{l}.055 \\
.026 \\
.081 \\
.140 \\
.084\end{array}$ & $\begin{array}{r}245 \\
332 \\
1,013 \\
353 \\
716\end{array}$ & $\begin{array}{r}95 \\
26 \\
274 \\
116 \\
260\end{array}$ & $\begin{array}{l}1.7 \times 10^{4} \\
7.3 \times 10^{2} \\
2.8 \\
5.3 \times 10^{2} \\
3.6\end{array}$ & $\begin{array}{r}61 \\
27 \\
3 \\
22 \\
11\end{array}$ & $\begin{array}{l}210 \\
279 \\
605 \\
260 \\
530\end{array}$ & $\begin{array}{r}78 \\
14 \\
90 \\
52 \\
174\end{array}$ & $\begin{array}{l}1.3 \times 10^{7} \\
1.5 \times 10^{4} \\
2.8 \\
2.6 \times 10^{4} \\
3.6\end{array}$ & $\begin{array}{l}90 \\
48 \\
17 \\
60 \\
16\end{array}$ \\
\hline $\begin{array}{l}46 \\
47\end{array}$ & $\begin{array}{l}\text { Unidentified sandy loam } \\
\text { Unidentified silt loam.............. }\end{array}$ & $\begin{array}{l}.186 \\
.237\end{array}$ & $\begin{array}{l}.011 \\
.030\end{array}$ & $\begin{array}{l}79.3 \\
20.7\end{array}$ & $\begin{array}{l}4.4 \\
1.4\end{array}$ & $\begin{array}{l}.18 \\
.30\end{array}$ & $\begin{array}{l}.08 \\
.09\end{array}$ & $\begin{array}{l}.545 \\
.762\end{array}$ & $\begin{array}{l}.040 \\
.120\end{array}$ & $\begin{array}{l}540 \\
270\end{array}$ & $\begin{array}{l}96 \\
84\end{array}$ & $\left|\begin{array}{l}6.2 \times 10 \\
2.1 \times 10^{3}\end{array}\right|$ & $\begin{array}{r}2 \\
54\end{array}$ & $\begin{array}{l}331 \\
134\end{array}$ & $\begin{array}{l}52 \\
28\end{array}$ & $\left|\begin{array}{l}7.1 \times 10^{2} \\
1.2 \times 10^{10}\end{array}\right|$ & $\begin{array}{r}26 \\
550\end{array}$ \\
\hline
\end{tabular}


Attention is called to the values of $k, a$, and $n$ in order that the reader may realize how greatly soils differ, and also to the standard errors of these values so that he can see the erratic nature of soil corrosion, even under conditions that are somewhat less diverse than those frequently encountered by pipe lines.

In columns 11 and 15 of table 4 are shown the computed averages of the maximum pit depth to be expected on a group of 8-in. pipes $1,000 \mathrm{ft}$ long and 30 years old. The standard errors in columns 12 and 16 are a measure of the variations that may be expected from the listed pit depths. The standard errors $\left(\sigma_{p}\right)$ for the pit depths derived by Scott's equation are computed by means of the equation

$$
\left(\frac{\sigma_{p}}{P}\right)^{2}=\left(2.3 \sigma_{a} \log A\right)^{2}+\left(2.3 \sigma_{n} \log T\right)^{2}+\left(\frac{\sigma_{k}}{k}\right)^{2}
$$

The standard errors for the pit depths derived by Ewing's equation were calculated from the equation

$$
\frac{\sigma_{p}}{P}=\left(\frac{\sigma_{c} \log A}{C \log A+1}\right)^{2}+\left(2.3 \sigma_{n} \log T\right)^{2}+\left(\frac{\sigma_{k}}{k}\right)^{2}
$$

In these equations $\sigma$ is the standard error of the quantity indicated by the subscript. The other letters have the same significance as in the other equations. In table 4 the unit of area is $0.4 \mathrm{ft}^{2}$ and the unit of time is 5.3 years. The large values of the standard errors of $P$ show that columns 11 and 15 indicate only the order of magnitude of the pit depths to be expected under the assumed conditions.

Columns 13 and 17 show the computed average length per puncture for a 30-year-old 8-in. pipe line having a wall thickness of 0.322 in. Columns 14 and 18 show the estimated time required for the development of an average of 1 leak per 1,000 ft on 8-in. pipes having a wall thickness of 0.322 in. It can be shown that if the extrapolation of the pit-depth data is large with respect to either the area exposed or the period of exposure, the standard error of the estimate is correspondingly large. Since many of the computed lengths and times are very long, their standard errors are very great, and consequently they indicate only that the corresponding soils are not very corrosive.

Figure 3, which is plotted from data in table 4, shows graphically the estimated maximum depth of pit on 1,000 ft of 30-year-old 8-in. pipe and the standard errors of the estimates. The standard errors of the predictions are such that in most cases the values predicted by one equation fall within the average predicted by the other plus or minus once or twice its standard error. For smaller extrapolations the results obtained by the two equations would of course differ less.

Although the data in table 4 must be recognized as rough approximations, they are of use to those interested in selecting the proper thickness for a pipe wall or in determining whether a protective coating should be applied.

The relative depth of pits on pipes in different soils varies with the area of the exposed material and with the period of exposure. Column 5 shows the pit depths on $0.4 \mathrm{ft}^{2}{ }^{2}$ after 5.3 years of exposure. If the data in this column are compared with those in columns 14 and 18 , it will be seen that although after 5 years' exposure the specimens in Cecil clay loam, soil 3, were pitted more deeply than those in Chester loam, soil 4, a pipe in the first-named soil would last much longer than one in the other soil. 


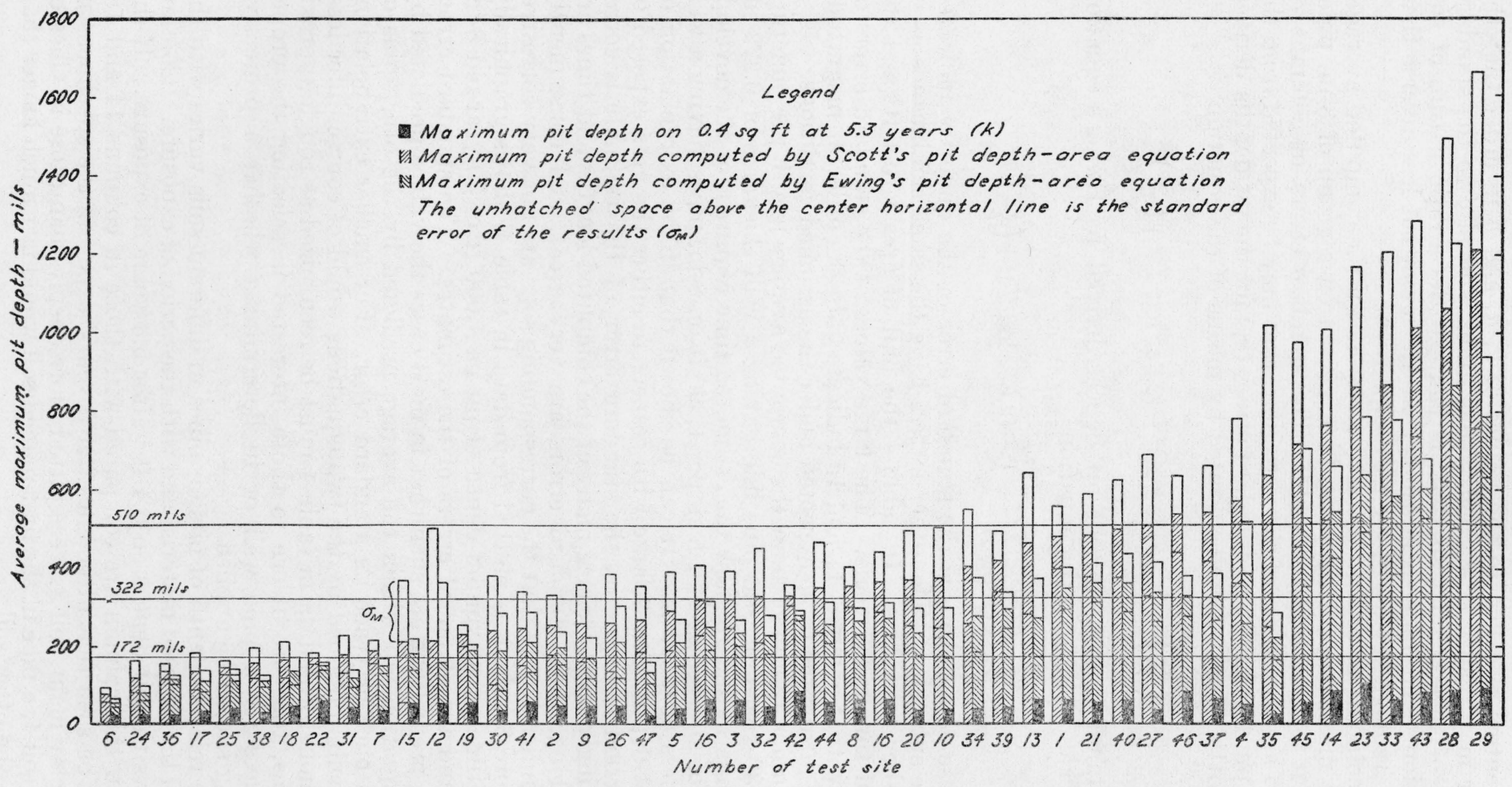

a Maximum pit depth on $0.4 \mathrm{sg} f t$ at 5.3 years (k)

Maximum pit depth computed by Scott's pit depth-area equation

NMaximum pit depth computed by Ewing's pit depth-areo equation

The unhatched space obove the center horizontal line is the standard error of the results $\left(\sigma_{\text {me }}\right)$ 
One hundred seventy-two mils has been suggested as the permissible thickness for 8-in. water-supply pipe for pressures up to $250 \mathrm{lb} / \mathrm{in}^{2}{ }^{2}$ An examination of column 11 indicates that within 30 years such an unprotected pipe would average at least 1 puncture per $1,000 \mathrm{ft}$ in 38 of the 47 soils. According to column 15, punctures on the same length would occur in 34 of the 47 soils. A good protective coating would of course reduce the number of punctures. Since supply lines frequently are readily accessible, the cost of repairing them may not be great and it is quite possible that the cost of repairs would be less than the cost of a protective coating or of thicker pipe. The table therefore does not indicate that light-weight pipe should not be used. Column 15 indicates that standard-weight steel pipe (0.322 in.) would develop a leak in 14 soils and class $B$ cast-iron pipe (0.51 in.) in 7 soils under the same conditions.

It has already been said that probably Ewing's pit-depth-area equation represents available data somewhat better than Scott's.

Table 4 shows that Ewing's equation results in the prediction of shallower pits, fewer leaks and longer pipe life.

\section{COMPARISON OF TEST DATA WITH FIELD EXPERIENCE}

Much has been said about the value of experience in estimating the corrosivity of soils. It is difficult, however, to express experience in sufficiently definite terms to make the information usable in the way that the results of tests are used, because the conditions under which the data of experience are obtained are often poorly defined, and because observations of identical conditions are usually not numerous enough to permit an estimate of the standard error or reproducibility of the experience. When experiences are analyzed it is often difficult to determine their exact significance or their applicability to some new condition. Experiences are frequently contradictory and they may be the results of some unrecognized conditions. They should therefore be examined carefully if they are to be applied to new construction.

Since the National Bureau of Standards soil-corrosion tests were conducted with the cooperation of operators of pipe lines who furnished the test sites and local labor, it might be assumed that a comparison of the Bureau's data with the field experience of the cooperators would furnish a key to the application of the results of the tests to pipe-line corrosion. When such a comparison is attempted a number of difficulties are encountered. Although there are pipes in the vicinities of most of the test sites, their extent in the soils of the test sites can be determined only by extensive soil surveys. Most of the pipe lines originally carried some kind of a protective coating. In many cases this coating was very thin and imperfect, although in some instances the coatings were quite heavy. In certain cases the lines have been reconditioned and the kind of coating changed from time to time. Most pipe lines carry currents which tend to protect certain portions of the line at the expense of other portions. Pipe networks in cities are frequently affected by stray currents from street railways, which modify the corrosive effects of the soils. The interconnection of one variety of pipe material to another, such as the connection of copper, brass, lead, or galvanized steel to cast iron, wrought iron, or steel mains, introduces additional galvanic corrosion. The passage of a line through two different soils sets up a galvanic current. The pipe 
which lies in the same type of soil as the test specimens may be buried deeper or shallower, and thus lie in a soil horizon that is quite different in texture, aeration, acidity, or resistivity from that of the specimens. The interconnection of a new pipe with an old one sets up a condition which may accelerate the corrosion of the newer line. Two pipes of the same material in the same street or right-of-way may corrode at different rates. In many cases records of the pipe lines are incomplete. In other cases the owners are reluctant to disclose their experiences because of possible effects on the valuation of their lines or the rates they may be allowed to charge for amortization as common carriers. For these reasons and others, no general comparison of the test data with the conditions of pipe lines has been attempted. However, a few comparisons will be made where conditions are especially favorable for such comparisons, although in no case are the conditions affecting the pipe line identical with those affecting the test specimens, and it is impossible to evaluate the effect of the differences accurately.

Soil 1. Allis silt loam.- Severe corrosion of service pipes in this soil has been reported, but definite data are not available. Ewing's equations indicate an average of 1 leak per 1,000 ft. of 8-in. steel pipe in 25 years.

Soil 8. Fargo clay loam.-This" soil is"similar to much of that in the city of Winnipeg, where severe corrosion of cast-iron water mains has been reported. Originally, the corrosion was attributed to straycurrent electrolysis, but the extent of the corrosion attributable to stray currents has not been established. Ewing's equations indicate that in this soil an 8-in. steel pipe should develop in 30 years an average maximum pit depth of 266 mils on a $1,000-\mathrm{ft}$. length.

Soil 9. Genesee silt loam.-A 6-in. steel line paralleling the test site was renewed because of corrosion after 14 years. Ewing's equations indicate that this soil is not corrosive.

Soil 15. Houston black clay. - Severe corrosion of cast iron and steel has been reported in this soil. Table 4 indicates that this soil is not very corrosive.

Soil 23. - Leaks developed on an 8-in. steel line in this soil within 5 years. Table 4 shows this soil to be very corrosive.

Soil 2\%. Miller clay. - Frequent leaks developed on a 12-in. line in this soil in about 9 years. The data in table 3 are from observations on such a line in Miller clay somewhat better drained than that in which the specimens were buried. Ewing's equations indicate that an 8-in. steel pipe should average 1 leak per $1,000 \mathrm{ft}$ in 27 years.

Soil 28. Moniezuma clay adobe.-This is said to be a very corrosive soil, but no specific data have been obtained. Table 4 shows this to be one of the most corrosive soils tested.

Soil 29. Muck. - Water mains in the vicinity of the test site corrode rapidly. The corrosion was attributed to electrolysis at one time, but the cause of the corrosion has not been definitely determined. Table 4 shows this to be one of the most corrosive soils tested.

Soil 32. Ontario loam.- The test site lies within a few feet of a 38-in. steel water main having a $5 / 8$-in wall. Within $2,000 \mathrm{ft}$ of the test site this line developed 25 leaks in 42 years. The line was protected by a japan varnish baked on. The length of the pipe in this soil at this location is 7,480 ft, in which length there were 50 leaks, or an average of 1 leak for $150 \mathrm{ft}$ in 42 years. According to Scott's pit-depth-area equation, the National Bureau of Standards data indicate there 
should have been an average of 1 leak in $5,349 \mathrm{ft}$ of pipe. The formula of Ewing would indicate that the length per leak should be greater. The Bureau's data show that in this case the soil is much less corrosive than experience proved it to be. However, this steel main is paralleled by a 36 -in. wrought-iron main having a $3 / 8$-in. wall which has developed no leaks in this soil in 61 years. The difference in the two experiences is greater than the difference between the test data and experience.

The difference in the performance of the two pipe lines may be explained in several ways. The materials used were different as were the protective coatings. It has been shown, [10] in certain cases at least, that when a new pipe is connected to an old one the latter is protected at the expense of the former. As for the difference between the results calculated from the tests and the leak records of the two pipe lines, it is obviously impossible for the experimental results to agree with both experiences. Most of the leaks on the steel line occurred on the top three-fifths of the pipe. This is rather unusual, as most cases of isevere corrosion occur on the bottom of the line. The severe corrosion of the steel line may be the result of a difference in soil conditions at the top and the bottom of the pipe or because the coating on the top of the pipe was injured by the backfill. The record of these pipe lines illustrates very well how conditions not duplicated in a test may alter the results when the material tested is used in a practical way.

Soil 35. Ramona loam.-The specimens at this site are laid adjacent to a 6 -in. cast-iron gas main which has carried gas for 29 years without developing a leak in the city block containing the specimens. This block also contains five services, one of which served without a leak for more than 25 years. Another service developed a leak in 9 years. Using Scott's pit-depth-area relation, the average of the maximum pit depths for $500 \mathrm{ft}$. of 6 -in. cast iron is 468 mils for a period of 29 years. This indicates that the cast-iron pipe in this soil, the wall thickness of which is 430 mils, should have developed, on the average, one puncture per block at the time the information was obtained. However, the comparison of the field and experimental data is of doubtful value because the extent of the pipe in Ramona loam has not been determined, because the pitting factor for cast iron being greater than for steel the value for " $a$ " should be less, and because cast iron may be punctured by corrosion and still carry low-pressure gas without leaking.

Although a review of these comparisons of test data with field experience indicates no very close relation between the two, usually the soils which the test has shown to be corrosive are shown by experience also to be corrosive. Corrosion is affected by so many factors that it can scarcely be expected that any test could completely duplicate the conditions which buried metals encounter in service. Knowledge of service conditions is in most cases so incomplete that it would be difficult to use an equation that took account of all significant field conditions even if such an equation could be developed.

\section{SUMMARY}

The corrosion of pipe lines depends on a number of factors which make it impossible to fully report underground-corrosion phenomena in the terms commonly used for the reporting of corrosion data. For 
this reason the data presented in previously published reports on the National Bureau of Standards soil-corrosion investigation do not give readers a clear and adequate idea of the corrosiveness of soils with respect to pipe lines. This is especially important with respect to maximum pit depths.

The maximum pit depth observed on any area will, on the average, be less than the maximum pit depth on a larger area exposed to the same conditions.

Pits usually change in depth more slowly as they become older, but this change, as well as the pit depth, differs greatly for different soils. It is therefore necessary to accompany rates of penetration by data on the effects of area and time if the pit depths are to be used for an estimation of the life of pipe. Such estimates should be based on data for the particular soil conditions associated with the pipe rather than on rates of penetration for average soil conditions.

The relative depths of pits on two materials or on the same material exposed to two soils may differ for different periods of exposure or for different exposed areas.

A number of empirical equations have been developed by investigators for the purpose of expressing the relations of area and time to maximum pit depths. All of these equations represent some observations on pipe lines approximately, but no one equation fits every set of pipe-line data better than any other equation.

The most generally applicable equation for the relation of pit depths to time and area of exposure is $P_{2}=P_{1}(C \log A+1) T^{n}$, in which $P_{2}$ is the average of the deepest pits on a number of specimens having areas $A$, and $T$ is the age of the specimens. $P_{1}$ is the pit depth on a unit area exposed for a unit time and $C$ and $n$ are constants which depend on soil characteristics. This and another equation have been applied to the data from the soil-corrosion investigation, and the maximum pit depths for 1,000 ft of 8-in. pipe have been computed for a time of 30 years. The results give a better indication of the corrosiveness of the soils investigated than can be obtained directly from an examination of the data on the test specimens.

Some of the soils which produced relatively high initial rates of corrosion are shown to be less destructive to pipe lines than others with lower initial rates of corrosion. On the whole, more of the 47 soils tested are shown to be seriously corrosive than were thought to be corrosive by some who examined the results of the investigation in their original form. From this it follows that unprotected lightweight pipe is suitable for use in fewer soils and protection to pipe is more generally needed.

The standard errors of the computed values are quite large and the results must be considered as only roughly approximating the behavior to be expected of a pipe line under practical conditions.

To test the reliability of the adjusted data, comparisons have been made between these data and the corrosion of pipe lines near some of the test sites. In view of the fact that two pipe lines in the same locality do not always corrode alike, a close agreement between the calculated and observed behavior of a pipe is not to be expected. Comparisons between experience and predictions of corrosion based on experiments are frequently unsatisfactory because the pipe lines may be subjected to influences not represented in the experiment. In 
general, however, the observed correspondence is sufficiently good to warrant the conclusion that if local conditions are properly taken into account, the results of the soil-corrosion investigation properly adjusted for the effects of area and time constitute the best available basis for decisions as to the proper wall thickness and the necessity for protection of a proposed pipe line.

Much valuable assistance in the calculation and checking of the data has been received from R. B. Darnielle and W. H. Johnson and M. Romanoff. I. A. Denison and S. P. Ewing have made helpful suggestions as to the treatment and interpretation of the data.

\section{REFERENCES}

[1] K. H. Logan and V. A. Grodsky, Soil-corrosion studies, 1930. Rates of corrosion and pitting of bare ferrous specimens. BS J. Research \%, 1 (1931) RP 329.

K. H. Logan and R. H. Taylor, Soil-corrosion studies, 1932. Rates of loss of weight and pitting of ferrous and nonferrous specimens and metallic coatings, BS J. Research 12, 119 (1934) RP 638.

K. H. Logan, Soil-corrosion studies, 1934. Rates of loss of weight and pitting of ferrous specimens. J. Research NBS 16, 431 (1936) RP 883.

[2] Symposium on Corrosion Testing Procedures, Am. Soc. Testing Materials, p. 95 (1937).

[3] E. R. Shepard, Some factors involved in soil corrosion. Ind. Eng. Chem. 26, 723 (1934).

[4] G. N. Scott, Adjustment of soil corrosion pit depth measurements for size of sample, Proc. Am. Petroleum Inst. 14, pt. 4, 204 (1934).

[5] E. P. Fetherstonhaugh, Discussion of underground corrosion, Proc. Am. Soc. Civil Engrs. 101, 828 (1936).

[6] J. F. Putnam, Sorl corrosion, Proc. Am. Petroleum Inst. 16, pt. 4, 66 (1935).

[7] J. F. Brennan, A mathematical theory of corrosion, Gas Age Record 75,359 (1935).

[8] G. Corfield, Running a soil survey on a large distribution system, Western Gas 6, No. 3, 25 (1930).

[9] G. N. Scott, A preliminary study of the rate of pitting of iron pipe in soils, Proc. Am. Petroleum Inst. 14, pt. 4, 212, 1934.

[10] K. H. Logan, Walter Rogers, and J. F. Putnam, Pipe Line Currents, Am. Petroleum Inst. Prod. Bul. 204. p. 116 (1930).

Washington, September 20, 1938. 